\title{
Affinity, arming, consequences, and perceptions: an introduction
}

\author{
Todd Sandler ${ }^{1}$
}

Received: 18 September 2018 / Accepted: 28 September 2018 / Published online: 3 October 2018 (c) Springer Science+Business Media, LLC, part of Springer Nature 2018

\begin{abstract}
This article provides an introduction to the special issue on Political violence: affinity, arming, consequences, and perceptions. The issue contains panel analyses, theoretical investigations, and a quantification study. With respect to terrorism, four of the articles study perceptions regarding democratic skepticism, security effectiveness, refugee hosting risks, and financial well-being. Although much of the special issue addresses aspects of terrorism, some articles consider other political violence topics, such as UN peacekeeping, civil war, and war outbreak. This introductory article also summarizes each of the eight contributions.
\end{abstract}

Keywords Transnational and domestic terrorism · Terrorism consequences · Arming · UN peacekeeping $\cdot$ Perceptions

JEL classifications D74 · F50 $\cdot$ H56

\section{Introduction}

Unfortunately, political violence is an ever-present phenomenon during the post-Cold War era and manifests itself in terms of intrastate civil wars, coups d'état, guerrilla warfare, insurrections, election violence, and terrorism. The primary purpose of this special issue is to cast light on some topical aspects of political violence, which include the human costs of terrorism, the outbreak of war, the consequences of hosting refugees, UN involvement in peacekeeping, and root causes of terrorism.

Given that five of the eight special-issue articles address various facets of terrorism, a clear definition is required. Terrorism is the premeditated use or threat to use violence against noncombatants by individuals or subnational groups to obtain political objectives by intimidating a large audience beyond that of the immediate victims (Enders and Sandler 2012, p. 4). To qualify as a terrorist act, the attack must seek an identifiable political objective. Kidnapping for ransoms to support a group seeking, say, to remove US forces from

Todd Sandler

tsandler@utdallas.edu

1 Department of Economics, School of Economics, Political \& Policy Sciences, University of Texas at Dallas, 800 W. Campbell Road, Richardson, TX 75080, USA 
the country constitutes a terrorist attack. Terrorist attacks may assume the form of bombs planted in public places (e.g., open-air markets) or armed attacks staged at airports in order to extort political concessions. Terrorists often resort to attacks with ghastly consequences so that a targeted constituency pushes for an accommodation with the terrorist group in a desperate attempt to restore tranquility. In recent years, terrorists unleashed attacks-mass shootings, large-scale explosions, suicide bombings, and vehicle rammings - to ratchet up the killing and maiming of their victims (Arce 2018). Such horrible acts draw media attention and heighten anxiety. The seeming randomness of those heinous acts creates a general atmosphere of insecurity. ${ }^{1}$

Terrorism can be characterized as domestic and transnational (Enders et al. 2011; Gaibulloev and Sandler 2019). Domestic terrorism is country-centered in which the perpetrators, victims, and intimidated audience are nationals from the venue country, the scene of the incident. An example involves the abduction of Aldo Moro, a former prime minister of Italy, by the Italian Red Brigades on March 16, 1978. Moro later was murdered on May 9, 1978 when the terrorists' political demands had not been met. The Unabomber's (Theodore Kaczynski's) 17-year bombing campaign during 1978-1995 against US airline and university targets constitutes domestic terrorist attacks. By contrast, transnational terrorist attacks entangle two or more countries through their perpetrators, victims, or venue. For instance, the truck ramming of five Argentine citizens, a Belgian national, and many others on a bike path in downtown Manhattan on October 31, 2017 by an Islamic State sympathizer is a transnational terrorist event. The coordinated shootings and bombings in Paris on November 13-14, 2015 by Islamic State operatives represent transnational terrorist attacks because victims and perpetrators included, among others, foreign nationals. Moreover, some of the terrorists in those Paris attacks crossed French borders both before and after the incidents. The crossing of borders before, during, or after an attack is another characteristic of transnational terrorism.

Both types of terrorism generate externalities - uncompensated costs or benefits-for individuals, who are not involved directly in the incident. Domestic terrorist attacks may result in higher insurance premiums for nontargeted firms, which correspond to a negative externality. Individuals who support the group's objectives benefit indirectly from successful attacks. Moreover, the threat of domestic terrorism raises tax-supported homeland security spending, which also is an externality. Transnational terrorism leads to transnational externalities or uncompensated consequences that affect countries beyond the targeted countries. For example, terrorism in one or more trading partners results in tighter surveillance of exports that, in turn, raises the price to importing countries (Bandyopadhyay et al. 2018). Terrorist attacks can disrupt the supply of imports, the flow of foreign direct investment, or the volume of tourism, all of which possess external cost components. Gaibulloev and Sandler (2018) show that countries that take UN positions similar to those of the United States and its three major Western allies (Britain, France, and Germany) attract more terrorism. That affinity-generated terrorism represents an externality that is shown to be robust (Dreher and Gassebner 2008). Based on micro-level evidence from Pakistan, Gaibulloev et al. (2018) find that terrorism reduces citizens' subjective financial wellbeing. The lost well-being is another terrorism-generated externality, which may be of the domestic or transnational variety, depending on the type of terrorism that lowered citizens' perceived well-being.

\footnotetext{
${ }^{1}$ For an informative analytical and conceptual history of terrorism, see Shughart (2006).
} 
The study of political violence includes theoretical studies, cross-country empirical analyses, and micro-level empirical exercises. The special issue's articles adopt all three of those methodologies. Garfinkel and Syropoulos (2018) present a purely theoretical investigation, whereas Arce (2018) offers a data-supported theoretical approach. Arce's parameters are quantified using measurements based on medical and terrorist-event data. Macrolevel empirical articles include Maekawa et al. (2018) and Gaibulloev and Sandler (2018). The former study applies pooled ordinary least squares regressions to the data; the latter study applies negative binomial regressions to panel data.

Generally, micro-level studies rely on event or survey data, gathered from different within-country locations. Micro-level exercises also may rely on respondents' answers to survey questions in two or more comparative countries, as in the Economou and Kollias (2018) study of security perceptions, following significant coordinated terrorist attacks in France. More commonly, micro-level analyses involve single-country surveys as in the studies by Piazza (2018) of the Palestinian Territories, by Braithwaite et al. (2018) of Lebanon, and by Gaibulloev et al. (2018) of Pakistan. Such within-country, micro-level analyses help avoid identification problems arising from cross-country dependence. Micro-level data may derive from already administered surveys or from author-generated surveys. If the authors do not ask the right (revealing) questions in original surveys, then their subsequent analysis may yield insignificant results, leading to a waste of time and money. Concerns may arise when a large number of respondents decline to answer sensitive questions, which serve as the dependent variables for testing various hypotheses. Nonrespondents may differ fundamentally from respondents, so that imputing data from respondents' answers is not legitimate unless this imputation painstakingly can be shown to be unbiased.

Currently, a huge divide exists between macro- and micro-level studies. Macro-level studies of large panels of countries may be plagued by cross-country dependence and identification difficulties. If unique conditions are associated with a studied country such as Israel or Pakistan, then generalizing from the micro-level country study's findings to the world at-large becomes problematic. Thus, researchers face a tradeoff when choosing between macro- and micro-level studies of political violence. What is the way forward to using both types of studies? For macro-level studies, methods (namely, factor augmentation) have been developed for adjusting for cross-sectional dependence (Gaibulloev et al. 2014). Additionally, identification strategies primarily include the development and use of instruments. To establish the sought-after generalization of micro-level country studies, a researcher first should look at the regional level to match another country on key variables with those of the studied country. That exercise is a first-cut attempt at generalization in which the uncovered findings are sought in a carefully matched regional partner. A validating second-cut effort is to conduct more follow-up micro-level studies on well-matched countries to test empirically whether or not the generalization holds. Further thought must be given to comparing macro- and micro-level studies, especially at the regional level where countries share many important characteristics in terms of ethnic composition, location, social factors, geo-climatic conditions, resources, and economic considerations.

\section{The articles in the special issue}

Gaibulloev and Sandler (2018) investigates whether countries that adopt foreign policy positions similar to those of prime-target Western nations - the United States, France, Germany, and the United Kingdom—are in greater peril for terrorism. That article carries 
forward the pioneering work of Dreher and Gassebner (2008), which shows that countries whose voting behaviors in the UN General Assembly are more closely correlated with that of the United States attracted more transnational terrorist attacks. The current study ventures beyond that earlier effort in a number of essential ways. First, Gaibulloev and Sandler use an ideal-points affinity indicator, along with the standard affinity measure, to establish the robustness of the affinity-terrorism nexus. The ideal-points affinity index distinguishes better between agenda and preference changes than the standard affinity measure. The latter indicator merely correlates UN General Assembly votes between the United States and those of another country. Second, Gaibulloev and Sandler apply alternative measures of terrorism that include transnational, domestic, and casualty-based attacks; the affinity-terrorism relationship is robust for these alternative measures. Third, Gaibulloev and Sandler include political affinity with the United States, political affinity with three major US allies (Britain, France, and Germany), and political affinity with the United States and its three allies. Fourth, Gaibulloev and Sandler establish that political affinity with the United States also results in more attacks on US interests abroad. Thus, political affinity with the United States not only puts aligned countries' interests at risk, but also jeopardizes US interests in US-aligned countries. As such, counterterrorism measures must protect US assets at home and in countries with US-aligned foreign policies.

Gaibulloev and Sandler estimate fixed-effects negative binomial regressions for 159 countries and ten 5-year periods, commencing in the late 1960s and concluding in 2014. Political orientation to Western foreign policy is shown to have costs in terms of larger and deadlier transnational and domestic terrorist attacks. Affinity-induced domestic terrorism arises as citizens engage in terrorist attacks at home to protest their country's foreign policy alignments with Western foreign policy preferences. As a consequence, political affinity generates far more serious consequences than first reported by Dreher and Gassebner (2008). Moreover, the political-affinity-inspired attacks also are entangled with the foreign policies of the three major US allies.

The second article is the only pure theoretical exercise in the special issue. Garfinkel and Syropoulos (2018) develop a one-period, full-information, guns-versus-butter scenario with two asymmetric rivals who vie for control over an insecure portion of their aggregate butter (civilian good) output. These agents can resolve their dispute through peaceful bargaining involving a resource transfer from the poorer to the richer country, or through war involving a resource transfer from the vanquished to the victor. The outcome of bargaining or warfare is based on the rivals' arming decisions. The choice of war or peace is made in advance of the arming choice, but after the resource transfer. With asymmetric adversaries, the better-armed rival is more likely to win a war, which is determined by a lottery contest success function. War destroys some of the contested, insecure butter output. If sufficiently severe, output destruction may make peaceful settlement more desirable. In a peace agreement, the insecure butter is again divided based on the rivals' arming decisions, with the larger share going to the better-armed opponent. However, peace results in no reduction in butter. The rich agent prefers war unless the associated destruction is too large. In contrast, the poor agent favors peace and is willing to transfer some resources to restrain the rich rival's incentive to go to war.

Garfinkel and Syropoulos argue that an enhanced resource transfer from the poorer country can have a greater pacifying influence on the richer country when the poorer country's butter output is less secure. Hence, output security is not necessarily supportive of peace. War's destructiveness, output security, and initial resource disparity are the three key drivers of the choice between war and peace in their full-information setting. Despite short-term commitments to war or peace prior to the agents' arming decisions, war can still 
erupt. Moreover, uncertainty is not needed as a cause of war. Their game-theoretic model is simple, elegant, and empirically predictive. One such application is to the Israeli-Palestinian negotiations associated with the Oslo Accords in 1993 (Garfinkel and Syropoulos 2018). Given its simple framework, the model can be extended in a number of directions.

To ascertain how much to spend on counterterrorism, a targeted country must know the consequences of transnational and domestic terrorist attacks on home soil. Those consequences include human costs, material losses, and political ramifications. Most terrorism event datasets-e.g., International Terrorism: Attributes of Terrorist Events (ITERATE) (Mickolus et al. 2018)—provide raw estimates of human losses (injuries and deaths), poor estimates of material losses, and no estimates of political consequences. Arce (2018) offers a thoughtful exercise at quantifying the human costs of terrorist attacks by greatly extending the earlier efforts of Sandler et al. (2009, 2011). Those earlier studies primarily quantified the human costs of bombings, which generally account for half of all terrorist attacks (Enders and Sandler 2012; Gaibulloev and Sandler 2019). Arce presents the death and injury tolls associated with alternative types of bombings, mass shootings, combined shootings and explosions, and vehicular assaults. In his study, bombings involve various venues and modes, such as confined spaces, open spaces, suicide attacks, vehicular deliveries (car and truck bombs), structural collapses, and structural fires. Arce's estimates of the resulting disability-adjusted lives lost (DALLs) and disability-adjusted life years lost (DALYs) are informed by medical studies that document the injuries and deaths associated with past terrorist incidents for each of his studied attack modes. Arce allows an attack mode to generate multiple injuries, such as primary, secondary, tertiary, and quaternary blast injuries. Those injuries may include damage to the lungs, tympanic membranes, thorax, abdomen, spine, limbs, head, and neck. In addition, mental disorders (e.g., post-traumatic stress) are included. What is most important, Arce controls for baseline incidences of morbidity and mortality in attack venues - not all injuries and deaths from, e.g., abdominal wounds, are the result of terrorism. His calculations show that mass shootings, combined shootings and explosions, and suicide bombings account for the largest DALLs in descending order. Vehicular assaults, a recent form of attack, have the fourth largest DALL.

Many policy-relevant insights stem from Arce's novel cross-sectional study. First, injuries increase DALLs by $51 \%$, compared to that for the annual number deaths from transnational terrorism worldwide. Injuries significantly raise the human consequences of terrorism and the subsequent justification for counterterrorism policies. Second, Arce shows that terrorism lies in the bottom $10 \%$ of the global burden of disease, which limits somewhat the attractiveness of counterterrorism expenditures. However, one must remember that the material and political costs of transnational terrorism are not included in his analysis. Moreover, many modes of terrorism (e.g., assassinations, skyjackings, and kidnappings) are excluded from the analysis. Third, Arce's informative ranking of the human consequences of terrorist attacks can be used when allocating home security resources to protect against various modes of terrorism.

Since 1948, the United Nations (UN) has been engaged in 71 peacekeeping operations (PKOs), 75\% of which were mobilized after 1990 (Sandler 2017). Scholarly interest in the political economy of peacekeeping blossomed in the last 20 years as UN PKO numbers, PKO complexity, and PKO expenditures have grown greatly. That scholarly interest in PKOs is fueled partly by the availability of data concerning financial contributions, personnel deployments, mission effectiveness, peacekeepers' casualties, civilian casualties, and mission characteristics. The 1998-2007 period witnessed a fairly steady rise in UN PKOs' expenditures; however, that spending leveled off somewhat after 2007 (Sandler 2017, Fig. 4). Maekawa et al. (2018) examine how UN involvement influences 
the implementation of peace agreements when commitment problems of the government and the rebels evolve. The peace process and its concomitant lull in conflict allow rebels to build up their capacity, thereby inhibiting their commitment to peace. Commitment may fail voluntarily based on rational calculations by the rebels and the government, or involuntarily based on a failed ratification process by the government. As the authors argue, the type of UN PKO deployed depends on the anticipated commitment problem, with involuntary commitment requiring observer missions. In contrast, voluntary defection requires large-scale PKOs that reduce the attractiveness of noncompliance on the part of the adversaries.

To implement their study, Maekawa et al. enter data from both the Peace Accords Matrix Implementation Data and the Personnel Commitment to UN PKOs dataset for 1989-2010. Among their findings, the authors show that large peacekeeper deployments improve the prognosis for peace agreement implementation. Involuntary defections reduce the extent to which peace agreements can be sustained. Polarized voting and electoral competition drive, in part, involuntary defection by the government that delays the achievement of peace agreements. The pre-agreement duration of conflict also can inhibit the achievement of a comprehensive peace agreement. The authors argue that greater state bureaucratic capacity can foster voluntary and involuntary commitment.

Piazza (2018) represents the first of the issue's four perception-based articles. His study unpacks the view that public skepticism of democracy as a suitable form of government may result in support of terrorism in Muslim countries. Piazza argues that terrorism-supporting individuals regard democracy as incompatible with the ideals of Islam. Moreover, he hypothesizes that individuals also reject democracy because they view it as being associated with poor economic outcomes in the Middle East. To test his democracy-based hypotheses, Piazza uses public opinion data drawn from the Palestinian Territories of the West Bank and the Gaza Strip. The data are taken from the Arab Barometer (AB) 1 and 4, conducted during spring 2006 and February 2016, respectively. In AB1, respondents were asked about their support for terrorist attacks directed against civilians in Iraq, while, in AB4, respondents were asked about their support for Islamic State terrorist attacks directed against civilians and foreign forces in the Middle East. The dependent variables correspond to respondents' support for terrorist attacks, based on a four-point ordinal scale, in two alternative locations and time periods. The primary independent variables refer to respondents' skeptical attitudes toward democracy, which is based either on incompatibility with Islam or poor economic performance. Across the two AB waves, similar proportions of respondents in the 29-39\% range perceived democracy as being incompatible with Islam or leading to poor economic performance. Piazza also includes demographic and attitudinal controls, employed in past research of public opinion and terrorism in Muslim countries.

As hypothesized, survey respondents were significantly more likely to favor terrorism if they opposed democracy. Democracy-skeptical respondents supported civilianbased attacks in Iraq and Islamic-State-based attacks in the Middle East. Respondents who viewed democracy as un-Islamic supported Islamic State's terrorist attacks, but not the Islamic State's goals. Finally, Piazza finds that respondents who viewed democracy as resulting in poor economic outcomes favored civilian terrorism in Iraq and Islamic State terrorism in the Middle East.

Like Piazza, Economou and Kollias (2018) investigate perceptions. In the latter study, the authors are interested in citizens' security perceptions following terrorist attacks in Paris, France, on January 7-9, 2015 and on November 13-14, 2015. On January 7, 2015, the initial Paris attack involved a mass shooting at the offices of the satirical newspaper Charlie Hebdo that resulted in 12 deaths and 11 injuries. Thereafter, other incidents ensued 
during January 7-9 in the Île-de-France region, where the most significant subsequent attack left four dead at a kosher supermarket during a hostage-taking seizure. Responsibility for the attacks was claimed by al-Qaida. The November 2015 incident, orchestrated by Islamic-State-affiliated terrorists, consisted of coordinated attacks outside a football stadium in Saint-Denis, at the Bataclan Theater, and at cafes and restaurants. The complex of attacks left 130 dead, with 89 deaths at the Bataclan Theater alone. Economou and Kollias use answers from French citizens to security perception questions contained in the Eurobarometer 85.1 survey, administered in April 2016. The authors compare the French responses to those of citizens in the remaining European Union (EU) countries. They also compare French responses to Greek responses, as well as to Dutch responses. Neither Greece nor the Netherlands suffered terrorist attacks near the time of the two sets of French attacks. Respondents' socioeconomic characteristics are used as controls in their study.

Economou and Kollias indicate that French respondents generally preferred more enhanced EU security than those in the general EU sample or in the Netherlands. The opposite was true for Greek respondents. Understandably, French respondents were more apprehensive about future terrorist attacks than were their counterparts in the Netherlands and Greece. The effects of the two sets of French attacks are shown to have a somewhat weak, short-lived effect on security perceptions. For the dyadic comparisons, a decomposition exercise attributes differences in security and radicalization perceptions to either behavioral reactions or respondents' characteristics. The short-term nature of French fear concerning terrorism risk following these French terrorist attacks agrees with the shortlived apprehension of tourists following high-profile hijackings (Enders and Sandler 1991; Enders et al. 1992).

Braithwaite et al. (2018) also investigate how individuals' past exposure to political violence frames their perceptions of risk associated with their home country's hosting of refugees. In particular, the authors focus on potential backlash of citizens to their government's hosting of Syrian refugees in camps near the Syrian border. Currently, Lebanon has taken in over a million refugees from the Syrian Civil War. Unlike the two previous articles, Braithwaite et al. administer their own surveys during the summer of 2017 to Lebanese respondents. Surveys preceded and followed suicide attacks against Lebanese military personnel near Arsal, carried out by Syrian rebels during late June 2017. Suicide attacks on June 30, 2017 coincided with actions by the Lebanese army to capture militants in a nearby refugee camp. On July 21, 2017, Hezbollah launched an offensive to apprehend militants in refugee camps and in surrounding territory near Arsal. Hezbollah represents domestic forces, whose coordination with the Lebanese military was intended to promote safety from refugee violence. As the authors emphasize, the first event by rebels should enhance residents' fears about hosting refugees, while the second event by Hezbollah should ameliorate those fears. The authors also hypothesize that the incident-induced apprehension in the first case should dissipate with time, while the lesser apprehension in the second case should occur with a lag. The lag allows the respondents to experience and then to judge the effectiveness of the security operation if the situation stays peaceful.

Braithwaite et al.'s empirical analysis mostly supports their hypotheses. In particular, following the June 30 incident, respondents' worries concerning refugees and rebels rose relative to the respondents' pre-incident views of refugees. Moreover, that post-incident apprehension diminished over time. In regards to Hezbollah's military actions, the results offer mixed support for the authors' hypotheses. Fifteen days after the incident, no significant reduction in respondents' concern for refugees or militants was evident, compared to respondents' pre-incident risk perception. However, the hypothesized reduced apprehension eventually showed up some 30 days after Hezbollah's operation. 
In the last article, Gaibulloev et al. (2018) examine how sustained exposure to terrorism in Pakistan affects individuals' views of their own financial well-being and that of their community. To answer their research questions, the authors combine terrorist incident data at the district level for 2004-2008 with information on perceived financial status and other variables from a nationwide household-level survey, administered to 6000 adults in Pakistan during 2009. By employing past terrorist events, the authors ameliorate potential simultaneity concerns between terrorism and risk perceptions. For controls, the authors use respondents' democratic, political, socioeconomic, and other characteristics (e.g., religious practices and views). Population density also is controlled for at the district level. The authors hypothesize that sustained terrorism creates financial anxiety because terrorist events can adversely affect gross domestic product, trade flows, foreign direct investment, and tourism (Gaibulloev and Sandler 2019). Those economic stresses are particularly dramatic in terrorism-plagued countries, such as Pakistan (Sandler and Enders 2008). Terrorism-induced economic stresses can be reinforced by psychological stresses that can further limit respondents' perceived financial well-being.

The authors' analysis shows that sustained district-level terrorist attacks reduced citizens' subjective financial well-being and their views about the financial well-being of the rest of the community. At a disaggregated level, low-educated residents and urban dwellers indicated larger declines in their own financial well-being relative to that of other respondents. The authors emphasize that terrorism-induced objective economic losses do not fully capture citizens' subjective losses in well-being. Those latter losses must be assessed to account more fully for the detrimental effect of a sustained terrorism campaign.

\section{Concluding remarks}

This special issue casts further light on political violence, which manifests itself in myriad forms-e.g., terrorism, civil war, and insurgency. The current issue is a companion issue to another special issue on Political violence [Public Choice 169(3-4) by me and published in December 2016]. That earlier issue contained no survey-based risk perception studies. Moreover, the topics addressed differ between those companion issues, with the earlier one examining terrorism and tourism, civil wars, oil and terrorism, refugee gravitation, coups d'état, piracy, and other topics.

In the current issue, the eight articles are drawn from 16 papers presented at the Eighth Conference on Terrorism and Policy, hosted by the Center for Global Collective Action at the University of Texas at Dallas in May 2018. The conference attracted established scholars from many different countries, including the United States. The participants were economists and political scientists. The 2018 conference was generously funded by the Vibhooti Shukla Endowment at the University of Texas at Dallas. Past conferences resulted in special issues published in Economics \& Politics (November 2009), the Journal of Conflict Resolution (April 2010), the Journal of Peace Research (May 2011), Public Choice (December 2011, December 2016), the Southern Economic Journal (April 2013), and Oxford Economic Papers (January 2015). William F. Shughart II, who was in attendance, advised me and provided comments on the papers. Prior to submission to the special issue, interested authors revised their conference papers based on comments from me, William F. Shughart II, and conference participants. Some papers were declined at a pre-screening stage and some papers were submitted elsewhere. All submitted papers went through a careful and rigorous reviewing process by anonymous referees. I thank all of the special 
issue reviewers, most of whom are major contributors to the study of political violence. A few reviewers are up-and-coming young scholars. The issue offers numerous interesting findings and insights.

Acknowledgements Special thanks are due to William F. Shughart II, who provided content and editorial assistance on all articles of this special issue.

\section{References}

Arce, D. G. (2018). On human consequences of terrorism. Public Choice. https://doi.org/10.1007/s1112 7-018-0590-9.

Bandyopadhyay, S., Sandler, T., \& Younas, J. (2018). Trade and terrorism: A disaggregated approach. Journal of Peace Research, 55(5), 656-670.

Braithwaite, A., Chu, T. S., Curtis, J., \& Ghosn, F. (2018). Violence and the perception of risk associated with hosting refugees. Public Choice. https://doi.org/10.1007/s11127-018-0599-0.

Dreher, A., \& Gassebner, M. (2008). Does political proximity to the U.S. cause terror? Economics Letters, 99(1), 27-29.

Economou, A., \& Kollias, C. (2018). Security policy preferences of EU citizens: Do terrorist events affect them? Public Choice. https://doi.org/10.1007/s11127-018-0612-7.

Enders, W., \& Sandler, T. (1991). Causality between transnational terrorism and tourism: The case of Spain. Terrorism, 14(1), 49-58.

Enders, W., \& Sandler, T. (2012). The political economy of terrorism (2nd ed.). New York: Cambridge University Press.

Enders, W., Sandler, T., \& Gaibulloev, K. (2011). Domestic versus transnational terrorism: Data, decomposition, and dynamics. Journal of Peace Research, 48(3), 319-337.

Enders, W., Sandler, T., \& Parise, G. F. (1992). An econometric analysis of the impact of terrorism on tourism. Kyklos, 45(4), 531-554.

Gaibulloev, K., Oyun, G., \& Younas, J. (2018). Terrorism and subjective financial well-being: Micro-level evidence from Pakistan. Public Choice. https://doi.org/10.1007/s11127-018-0606-5.

Gaibulloev, K., \& Sandler, T. (2018). Terrorism and affinity of nations. Public Choice. https://doi. org/10.1007/s11127-018-0611-8.

Gaibulloev, K., \& Sandler, T. (2019). What we have learned about terrorism since 9/11. Journal of Economic Literature, 57(2), forthcoming.

Gaibulloev, K., Sandler, T., \& Sul, D. (2014). Dynamic panel analysis under cross-sectional dependence. Political Analysis, 22(2), 258-273.

Garfinkel, M. R., \& Syropoulos, C. (2018). Problems of commitment in arming and war: How insecurity and destruction matter. Public Choice. https://doi.org/10.1007/s11127-018-0601-x.

Maekawa, W., Ari, B., \& Gizelis, T.-I. (2018). UN involvement and civil war peace agreement implementation. Public Choice. https://doi.org/10.1007/s11127-018-0602-9.

Mickolus, E. F., Sandler, T., Murdock, J. M., \& Flemming, P. (2018). International terrorism: Attributes of terrorist events, 1968-2017. Ponte Vedra: Vinyard Software.

Piazza, J. A. (2018). Democratic skepticism and support for terrorism in the Palestinian Territories. Public Choice. https://doi.org/10.1007/s11127-018-0596-3.

Sandler, T. (2017). International peacekeeping operations: Burden sharing and effectiveness. The Journal of Conflict Resolution, 61(9), 1875-1897.

Sandler, T., Arce, D. G., \& Enders, W. (2009). Transnational terrorism. In B. Lomborg (Ed.), Global crises, global solutions (2nd ed., pp. 516-562). Cambridge: Cambridge University Press.

Sandler, T., Arce, D. G., \& Enders, W. (2011). An evaluation of INTERPOL's cooperative-based counterterrorism linkage. The Journal of Law and Economics, 54(1), 79-110.

Sandler, T., \& Enders, W. (2008). Economic consequences of terrorism in developed and developing countries: An overview. In P. Keefer \& N. Loayza (Eds.), Terrorism, economic development and political openness (pp. 17-47). Cambridge: Cambridge University Press.

Shughart, W. F., II. (2006). An analytical history of terrorism, 1945-2000. Public Choice, 128(1-2), 7-39. 